\section{The sparkle of creativity}

Patricia A. Thistlethwaite, $\mathrm{MD}, \mathrm{PhD}$

$\downarrow$ Video clip is available online.

It has been my privilege to serve as the 43rd President of the Western Thoracic Surgical Association. This experience has been a great honor and certainly a highlight of my career.

When one stands up at the podium, you realize that this moment is not about you. Rather, it is a celebration of all the people who have inspired and supported you both in life and in surgery. I would like to recognize a few of these people. I grew up in a large family with 2 brothers and 2 sisters. I was the middle daughter and the fourth child. My siblings have had an enormous impact on who I am today. Growing up together, we supported each other in good times and in bad times, as only a family can.

My sister, Susie, is the eldest and is 11 years older than me. She is the free-spirit of the family. Susie recently retired from a long career as an anesthesiologist in Bethesda, Maryland. She raised 4 children, 3 of whom became physicians. I appreciate her motherly support and love, particularly when I was young.

My brother, Dick, is 1 year younger than Susie and 10 years older than me. He is considered the smart one in the family. Dick recently retired from a career as an abdominal transplant surgeon at the University of Chicago. He is 1 of the 3 surgeons who performed the first split-liver transplant in the world. His wife, Susan, is a PhD theologian and author of more than 10 books. Together, they have raised

From the Division of Cardiothoracic Surgery, University of California, San Diego, La Jolla, Calif.

This work was funded by National Institutes of Health (NIH) R01 HL119543 (PI) and NIH R01 HL132225 (PI).

Disclosures: The author reported no conflicts of interest.

The Journal policy requires editors and reviewers to disclose conflicts of interest and to decline handling or reviewing manuscripts for which they may have a conflict of interest. The editors and reviewers of this article have no conflicts of interest.

Read at the 45th Annual Meeting of the Western Thoracic Surgical Association, Olympic Valley, California, June 26-29, 2019.

Received for publication Jan 6, 2020; revisions received March 3, 2020; accepted for publication March 14, 2020; available ahead of print June 18, 2020.

Address for reprints: Patricia A. Thistlethwaite, MD, PhD, Division of Cardiothoracic Surgery, University of California, San Diego, 9300 Campus Point Dr, La Jolla, CA 92037-7892 (E-mail: pthistlethwaite@ucsd.edu).

J Thorac Cardiovasc Surg 2020;160:740-52

0022-5223/\$36.00

Copyright (c) 2020 by The American Association for Thoracic Surgery

https://doi.org/10.1016/j.jtcvs.2020.03.176
Check for updates

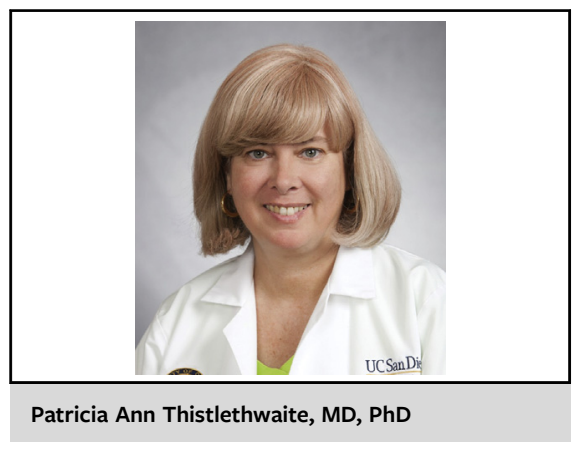

CENTRAL MESSAGE

Thinking creatively leads to new

discoveries and better ways to

do things, enhances personal

well-being and self-worth, and

ultimately benefits our patients.

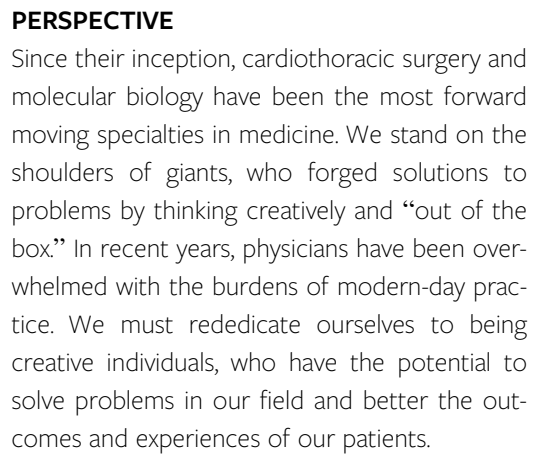

Since their inception, cardiothoracic surgery and molecular biology have been the most forward moving specialties in medicine. We stand on the shoulders of giants, who forged solutions to problems by thinking creatively and "out of the box." In recent years, physicians have been overwhelmed with the burdens of modern-day practice. We must rededicate ourselves to being creative individuals, who have the potential to solve problems in our field and better the outcomes and experiences of our patients.

James, a physicist and MBA in Chicago; Bill, a family practice doctor in northern Virginia; and Doug, an exhibit designer for the Exploratorium in San Francisco. I'm grateful for all the personal and professional advice that Dick has given me over the years.

My brother Bill was 2 years older than me. He was the star athlete of the family. Bill married a Southern girl, Mary Jane, and practiced general surgery for many years in Mayfield and Glasgow, Kentucky. He loved small-town life, coaching high school lacrosse and serving as the high school football team doctor. Bill and Mary Jane raised 2 phenomenal individuals: Taylor, an antique dealer in Washington, DC, and Clay, a geologist in Louisville. Last August, Bill was diagnosed with a very aggressive form 
of cancer. He succumbed to this disease in March. In the months before his death, we had many conversations together. He told me that no matter what, he would be here today for me. Bill, you are here in spirit. I am delighted that Bill's wife, Mary Jane and son, Clay, are here today to represent that branch of the family and celebrate my big day.

My sister Peggy and I grew up almost as twins, although I'm actually 2 years older than she is. She has been my confidant and close friend my entire life. She is a retired general surgeon, who has been married for many years to Bob, a urologist in Northern Virginia. Together they have raised 2 great children: Ashley, a lawyer in Central Virginia and Robby, a civilian defense contractor in Washington, DC. I'm so happy that Peggy and her family are here today to support me. Thank you.

It is easy to trace my interest in cardiothoracic surgery to the surgeons at the Massachusetts General Hospital. Drs Grillo and Vlhakes and the residents who worked under them were the most technically gifted and most knowledgeable of the entire hospital staff. After my general surgery residency at the Massachusetts General Hospital, I moved to Pittsburgh for my cardiothoracic surgery training at the University of Pittsburgh, under Dr Bartley Griffith. Dr Griffith is a true gentleman and pioneer in ventricular assist devices and heart and lung transplant surgery. He taught me a lot about heart surgery, a lot about how to be a leader, and a lot about life. Drs DiMarco and Kormos were consummate surgeons and superb teachers. I am grateful that they helped make me into the surgeon that I am today.

It is said that timing is everything in life. Completing a cardiothoracic surgery residency in 1997 was perfect timing, because a position opened up at the University of California, San Diego (UCSD). I am honored to have Dr Stuart Jamieson here today. What do you say to the person to whom you owe your career? I've learned from your guidance that the most important quality a chairman and mentor can possess is that he/she believes in you through mistakes and missteps and sees them as lessons learned. One who inspires you, gives you confidence, and keeps you on the ball. The greatest surgeons possess the following characteristics: maturity of judgment, dexterity of hand, devotion to teaching, serenity in crisis, and creativity in endeavor. You possess all of these qualities. I am honored to be your protégé. Michael Madani, my current chairman, I am awestruck by your technical ability, your passion for our specialty, and your eternal optimism. I have also been fortunate to work with Dr Brian Clary, our Chief of Surgery at UCSD. $\mathrm{He}$ is a visionary chairman, a "can-do" kind of guy, and a true physician-scientist. I would also like to acknowledge all the cardiothoracic surgeons in our division as dear friends and colleagues that I hold in highest esteem. Each is a dedicated, focused, academic surgeon who strives to make a difference every day and move our specialty forward. I thank all of you for your support and for being here today.

I have 2 close friends who I have known most of my life that I would like to mention. Dwight Nishimura and I met on our first day of college, as we were assigned to the same freshman dorm. He came from Hawaii, and I came from Maryland; about as far apart as 2 people can be from Palo Alto. Yet, we became the closest of friends. Dwight currently serves as the Chair of the Department of Electrical Engineering at Stanford. I so value all the phone conversations we have had over the years, covering every imaginable idea and subject. Dwight, you have been a true friend. Karen Parolin and I met in the early days of medical school, living in a Harvard dorm with a class of 160 men and just 10 women. She is a retired endodontist and is one of the most energetic people I know. A normal day for Karen would be to ride her bike 125 miles or climb an 8000-foot elevation mountain in a few hours. I am grateful for her friendship and the support that she has given me in good times and bad.

I found love late in life in the form of John Gwynne. It is as if opposites attract. John is a research psychologist and is a quiet, inquisitive person. He loves the great outdoors. His idea of a perfect day is to be walking alone in the wilderness. Together, he has shown me some of the most beautiful, remote places in California. We have also traveled the world together. I am grateful for his loving support through all the challenges and victories of life.

Finally, I would like to thank my parents. If they were alive today, my mother and father would have been very proud. My parents had the firm belief that children should be well-educated and independent. My father was a general surgeon who absolutely loved what he did. I saw this many times over, as he went out late at night to do emergency cases or when he missed family holidays and celebrations to take care of his patients. Several of his colleagues have told me that he was the most naturally-gifted surgeon they had ever seen. I wish I could have operated with him. One of his colleagues also told me that he was the type of person who would walk into Mortality and Morbidity Conference or case conference and sit quietly in the back of the room. Everyone in the front of the room would discuss and argue about patients and problems. After a while, all would turn to the back of the room, waiting to hear the final definitive opinion of my father. My dad also loved to fly fish, saying that trout lived in the most beautiful places in the world. He went on fly fishing trips on the Potomac River near my childhood home, as well as on excursions abroad, taking my mother along. She always wanted to be with him and make him happy.

With my dad's love of fishing, many of my life's lessons were learned while floating on a bass boat amongst the reeds of a sound or holding a surf rod at the ocean's edge. I am grateful for the goodness that was my father. He taught 
me the strength to jam my hands in my pockets and meet the wind and the salt in my eyes, to keep my balance on shifting sand, and to stand tall against the undertow of sadness and self-doubt. When I think of my father in all of his glory, it makes my heart sing.

My mother was the unsung hero of our family. She single-handedly raised 5 successful children, never complained, always led by example, stood for what she believed in, and most importantly, always put everyone else before herself. She was a true genteel, gracious Southern woman. I am grateful for the unconditional love that both my parents gave me.

Today, I would like to talk about the elusive topic of creativity. Let us begin in Istanbul, Turkey, near the Strait of the Bosphorus. In 532 A.D., at the beginning of the Middle Ages, the Roman emperor, Justinian I, commissioned the building of a great cathedral, called the Hagia Sophia (Figure 1). ${ }^{1}$ The cathedral was designed by 2 Greek mathematicians, Isidore of Miletus and Anthemius of Tralles. Neither individual had ever designed a building before. What was unique about the Hagia Sophia is its mammoth dome and underlying architectural support to hold up this dome. The dome measures 108 feet in diameter and 182 feet tall, is 2 feet thick and composed of mortar mixed with brick shards, and weighs 150 pounds per square foot. In contrast to all other Greek and Roman buildings up until that time, which had domes that rested on the external walls of buildings, the dome of the Hagia Sophia rested on 4 internal arches, held together at the top by pendentives or concrete triangular corners. The columns of the arches were marble and were mined from all over the Roman Empire, as far away as Ireland and Egypt. The architectural concept of this building was innovative in that the dome sat in a "tongue-in-groove" fashion into the circular opening formed by the top of the 4 pendentives and 4 arches, preventing lateral displacement of the base of the dome and collapse. $^{2}$ The pendentives overlying the columns of the arches held most of the weight.

In 1453, Constantinople was conquered by the Ottomans. Sultan Mehmet II rode his horse into the cathedral, proclaimed it the most beautiful building he had ever seen, and promptly declared it a mosque. In 1935, the building became a non-secular museum of Turkey. To this day, the Hagia Sophia is one considered one of the most

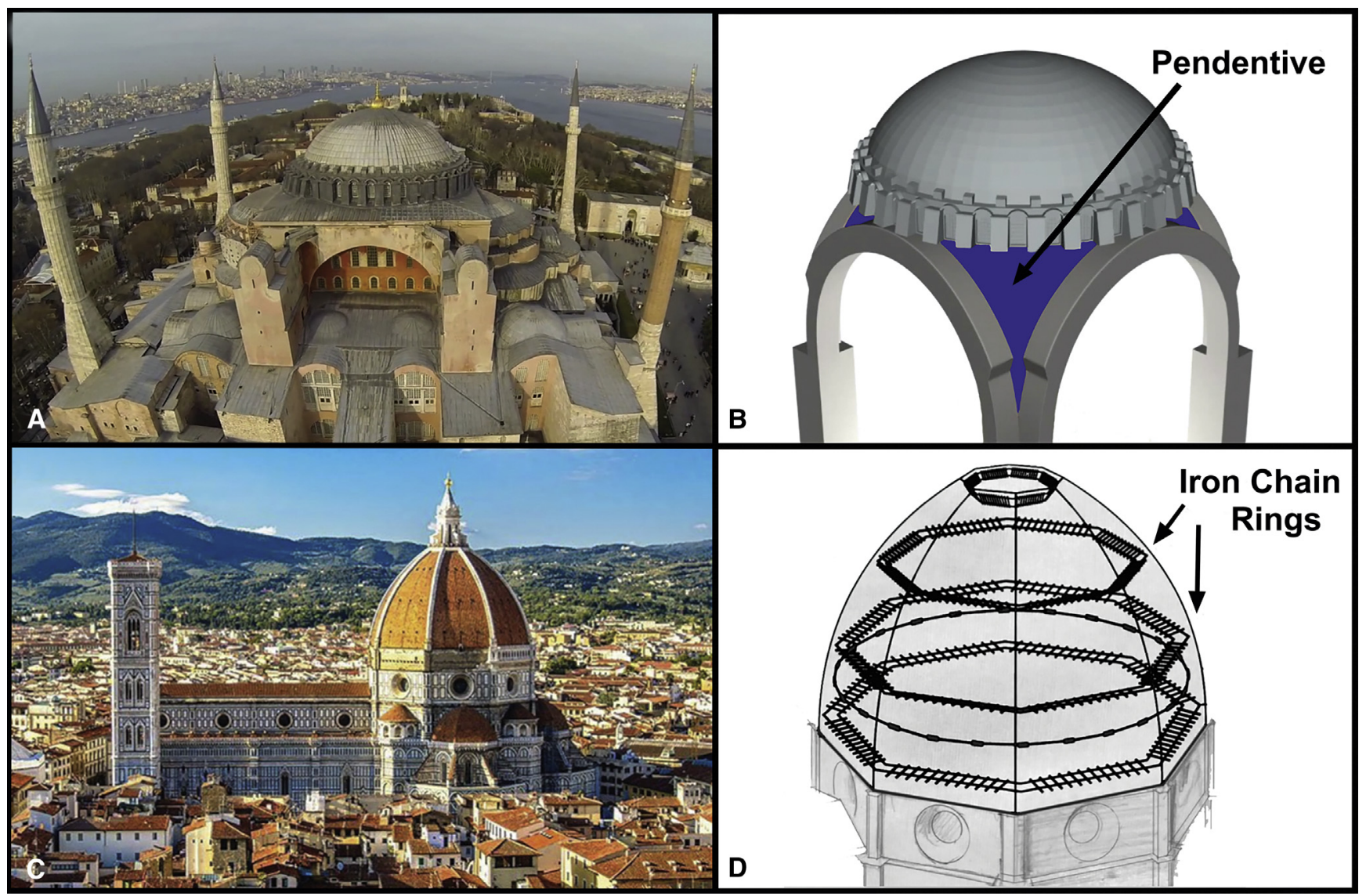

FIGURE 1. The innovative architecture of 2 domed buildings. The Hagia Sophia in Istanbul, Turkey (A); the dome of the Hagia Sophia is supported by 4 triangular pendentives connecting to 4 arches (B). The Duomo in Florence, Italy (C); the dome of the Duomo is held together by concentric iron chains embedded in sandstone (D). 
creatively-designed structures in the world and is the greatest surviving example of Byzantine architecture.

Seven hundred fifty years after completion of the Hagia Sophia, the townspeople of Florence, with the support of the Medici family decided to build a grand cathedral, named the Cathedral de Santa Maria del Fiore or Cathedral of Saint Mary of the Flower (Figure 1). ${ }^{3}$ Construction was begun in 1300 and the nave, or bottom portion of the building, was completed 118 years later. In 1418, a competition was held to pick the architect to design the dome that would cover the transept of the cathedral. A 35-year-old clockrepair man named Filippo Brunelleschi submitted an application and refused to reveal his architectural plans to the judging committee. He had never studied architecture, nor had he ever designed a building before this competition. Ultimately, he won the commission and designed one of the greatest masterpieces of the Renaissance. It took 16 years to build the dome, which was built on top of the outer octagonal-shaped walls of the transept. From each point of the octagon, 8 vertical curving ribs of sandstone were constructed to meet at the apex of the dome. The inner shell of the dome was made of brick, arranged in a herringbone pattern, while the outer shell of the dome was constructed of tile on marble. The design of the dome was innovative in that structural stability was achieved through the use of concentric horizontal, internal bands of sandstone and iron chain embedded within the inner dome, which served like barrel hoops, holding the dome structure in place and preventing lateral collapse. ${ }^{4}$

To this day, the Duomo di Firenze, as it is now called, is the largest brick masonry dome in the world. It is 125 feet wide, 376 feet tall, weighs 40,000 tons, and was constructed using over 4 million bricks. The Duomo is considered the greatest architectural achievement of the
Renaissance and an expression of unparalleled innovation and creativity.

Both of these grand structures were designed by men who had no architectural experience, yet they had a great creative vision. The architects of the Hagia Sophia and the Duomo never met one another, never studied each other's plans for their domed buildings, and came from different countries and cultures. They devised completely different solutions for the same problem: how to create a large domed building that has withstood the test of time. It is as if these creative individuals existed in parallel universes. I was born just before 1960, and during my lifetime, I have witnessed the burgeoning of 2 creative parallel universes in medicine - that of cardiothoracic surgery and genetics/molecular biology. Each is a young specialty, starting near the time of my birth. Both fields are, I believe, the most forward-thinking and innovative specialties in medicine today. We stand on the shoulders of giants. I would like to review some of the most creative moments in these 2 fields over the past 60 years (Figure 2).

\section{THE DEVELOPMENT OF THE PACEMAKER-1957}

In 1956, if one needed a pacemaker, you would be hooked up to a large device that required its own cart and relied on wall current for power. In October 1957, there was a 6-day blackout in Minneapolis, Minnesota. At that time, C. Walton Lillihei was beginning to correct congenital heart defects in children, using a cross-circulation technique with the mother. He realized that he needed a reliable way to pace his congenital heart surgery patients in the postoperative period. Dr Lillihei asked a 27 -year-old oscilloscope repair technician in the hospital, named Earl Bakken, to devise a portable, battery-driven pacemaker for human use. Four weeks after studying a circuit diagram for a

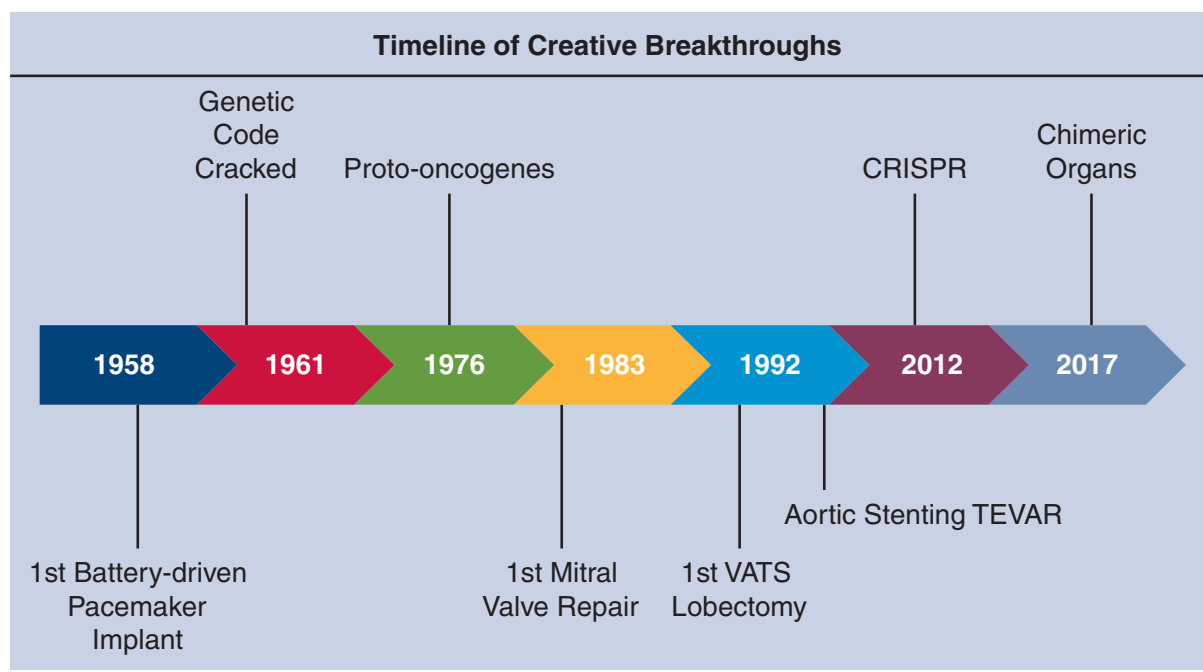

FIGURE 2. Timeline of creative events in cardiothoracic surgery and molecular biology from 1958 until present. CRISPR, Clustered regularly interspaced short palindromic repeats; VATS, video-assisted thoracoscopic lobectomy; TEVAR, thoracic endovascular aortic repair. 
metronome in Popular Electronics in his garage workshop, Mr Bakken delivered a battery-powered, transistorized, external pacemaker to Dr Lillihei. ${ }^{5}$ Much to Mr Bakken's surprise, the pacemaker was used the next day in an 8-year-old boy, who underwent atrial septal defect repair. The first fully implantable pacemaker was designed in Stockholm, Sweden, by an engineer named Rune Elmqvist and was first implanted by Drs Ake Senning and Clarence Crafoord at the Karolinska University Hospital in $1958 .^{6}$

If our goal as physicians is to alleviate suffering and to prolong meaningful life, I can think of no other invention that has been as effective. In 2018, there were 40 million people with pacemakers and 1.4 million pacemakers implanted worldwide. In the United States, there were 3 million people with pacemakers and 250,000 implanted that year. ${ }^{7}$ Now, Food and Drug Administrationapproved, implantable pacemakers are leadless and are smaller than the size of a nickel. Indeed, the Poon pacemaker that is powered and recharged remotely, which is under development at Stanford University, is smaller than a grain of rice. ${ }^{8}$ Clearly, the field of pacemaker technology has been a fertile area of creative design and innovation.

\section{CRACKING THE GENETIC CODE-1961}

In 1957, Francis Crick proclaimed, "I have solved the mystery of life." ${ }^{\prime \prime}$ Francis Crick had solved the chemical structure of DNA, but he had not solved the mystery of life. At that time, it was unknown whether DNA encoded amino acids, sugars, or other compounds. It took a 35year-old scientist from the National Institutes of Health (NIH), named Marshall Nirenberg, to crack the genetic code. Dr Nirenberg ran a small lab with one postdoctoral fellow. Although there were many large labs around the world that were trying to figure out what DNA encoded, including the lab of Francis Crick, Nirenberg thought that he would work on this problem. He hypothesized that the smallest "DNA word" or codon would be a nucleotide triplet that would encode a single amino acid. His reasoning was based on the fact that DNA contained 4 different nucleotides: adenine, guanine, cytosine, and thymine, whereas there were 20 known amino acids. Thus, one nucleotide could not encode one amino acid, because there were not enough nucleotides. Likewise, 2 nucleotides in random combination would yield only 16 permutations, so a doublet of nucleotides would not account for 20 amino acids. In 1961, Nirenberg devised his famous experiment to test whether a triplet of nucleotides would encode a single amino acid. ${ }^{10} \mathrm{He}$ used a cell-free system while the rest of the world was studying this question in bacteria. Nirenberg took Escherichia coli and ruptured their membranes with sonication, creating a bacterial-protein "soup." He placed this mixture into 20 test tubes. Into each test tube, he added a different single ${ }^{14} \mathrm{C}$-labeled amino acid and 19 other cold amino acids. Nirenberg then added poly-uracil (UUU) into each tube. He hypothesized that if UUU encoded a single amino acid, the cell-free mixture would start to produce a long chain of a single amino acid. If the ${ }^{14} \mathrm{C}$-labeled amino acid in the test tube was similar to the one being produced, the radiolabeled peptide would be incorporated into the growing peptide chain, which could then be isolated by size filtration through a series of membranes. On the first test tube he examined, he found that UUU stimulated the production of a long phenylalanine chain that incorporated the radiolabeled phenylalanine.

Nirenberg realized that he had cracked the genetic code for a single amino acid. Knowing that his lab was small and the competition was fierce, he called the heads of the each Institute at the NIH and asked them to bring their best researchers to his lab to help him perform the massive number of experiments that would be needed to put together all combinations of triplet nucleotides in his experimental system. They enthusiastically came and helped him, knowing that a Nobel Prize was likely at stake. This group effort has come to be known as "NIH's finest hour." In December 1961, the entire genetic code was determined. ${ }^{11}$ I grew up a few miles from the NIH in Bethesda, Maryland. There is a wonderful museum there where one can see the actual vial of UUU that Nirenberg used for his experiment. Marshall Nirenberg went on to win the Nobel Prize in Medicine in 1968 . He is the only scientist at NIH to have ever won a Nobel Prize.

\section{THE IDENTIFICATION OF PROTO-ONCOGENES IN THE HUMAN GENOME-1976}

In the 1970s, researchers who were interested in cancer were studying retroviruses, which caused tumors in chickens and mice. Scientists were sequencing the genomes of these viruses, which was not an easy thing to do at that time. They found specific genes in these viruses that encoded polypeptides, which they felt were crucial to carcinogenesis in animals. These viral genes were named "oncogenes." A young postdoctoral fellow in the laboratory of J. Michael Bishop, MD, at the University of California, San Francisco, named Harold Varmus, asked the simple question, "Does the human genome contain oncogenes, like those found in retroviruses?" He probed the human genome for these sequences and found, indeed, that every human cell contains what he termed "proto-oncogenes" or silent oncogenes. ${ }^{12}$ In normal cells, protooncogenes are not expressed and silenced. However, in cancer cells, proto-oncogenes are altered, either by: (1) deletion or point mutation, (2) gene amplification, or (3) chromosomal rearrangement causing splicing of nearby regulatory sequences next to the gene to induce overexpression or fusion of an actively-expressed gene with an oncogene, resulting in a protein that is hyperactive. ${ }^{13}$ 
Look at where this field has gone in the past 30 years. Now we know that there are specific oncogenic driver mutations in most forms of cancer. For example, in adenocarcinoma of the lung, there are now 14 known driver mutations (ALK, EGFR, MET, ROS being the most common), whereas in squamous cell carcinoma of the lung, there are 7 known driver mutations (FGFR1, KRAS, PIK3CA, and EGFR being the most common). ${ }^{14}$ Targeted molecular therapy drugs are now made to first-, second-, and third-generation mutations in these gene targets. Targeted therapy drugs have been remarkably effective. For example, a patient with stage 4 non-small cell lung cancer whose tumor harbors an EGFR exon 19 or 21 mutation has a 4-fold survival advantage at 40 months compared with a patient whose tumor lacks oncogenic mutation and who receives conventional chemotherapy. ${ }^{15}$

Today, liquid biopsies (blood biopsy) for cell-free circulating tumor DNA are being used for early screening for cancers, markers of recurrence of malignancy, and stratifying response and resistance of tumors to therapy. The identification of oncogenic driver mutations has led to molecular genotyping of tumors for targeted therapy, as well as drug development for personalized therapeutics. I suspect that, in the future, assays for cell-free circulating tumor DNA will become so sensitive and specific as to allow physicians to diagnose cancers before they are clinically manifest. For their discovery of proto-oncogenes and the mechanisms of their activation, Drs Varmus and Bishop were awarded the Nobel Prize in Medicine in 1989.

\section{MITRAL VALVE REPAIR-1983}

One of the paradigm-shifting changes in cardiac surgery occurred in 1983, when Alain Carpentier, MD$\mathrm{PhD}$, of the European Hospital of Georges Pompidou in Paris published his work on mitral valve repair in the Journal of Thoracic and Cardiovascular Surgery, entitled "Cardiac Valve Surgery-the French Correction."16 This paper outlined the basic pathophysiological classification of mitral valve lesions and provided the tools and essentially a game plan for how to successfully and reproducibly repair mitral valve regurgitation, particularly for degenerative myxomatous mitral valve disease. Many cardiac surgeons throughout the world were inspired by this paper to perform mitral valve repair instead of mitral valve replacement. Mitral valve repair was further refined by several other pioneers in this field, including Carlos Duran, MD-PhD, who recognized the importance of using a flexible mitral ring for recreation of a dynamic annulus, D. Craig Miller, MD, at Stanford, who showed that preservation of the posterior leaflet and chords preserved left ventricular geometry over time, Tirone David, $\mathrm{MD}$, at Toronto General Hospital, who I trained with and who recognized the importance of the fibrous trigone in designing partial rings, and Lawrence Cohn, MD, at the
Brigham and Women's Hospital, for his large series of patients who underwent mitral valve repair.

Today, mitral valve repair has been shown to be superior to valve replacement for many types of mitral stenosis and regurgitation, with the exception of severe rheumatic calcific mitral stenosis, mitral insufficiency in the setting of massive acute infarction, and mitral valve endocarditis where leaflets are destroyed. ${ }^{17}$ Whether one is performing a posterior leaflet repair with $\mathrm{P} 2$ resection or more complex anterior leaflet repairs with chordal reconstruction, mitral valve repair has come of age. In addition, the concept of valvular repair over replacement has led to pioneering repair techniques for the tricuspid and aortic valves in adults. Importantly, the basic principles of valve repair are now being used in designing percutaneous, less-invasive repairs of the mitral and tricuspid annuli and leaflets.

\section{VIDEO-ASSISTED THORACOSCOPIC LOBECTOMY AND THORACIC ENDOVASCULAR AORTIC REPAIR-1992}

1992 was a major year for innovation and creativity in cardiothoracic surgery, as this was the year that the first successful reports of video-assisted thoracoscopic lobectomy (VATS) and thoracic endovascular aortic repair (TEVAR) were published. Although several surgeons between 1920 and 1940 attempted to put probes, lights, and other instruments into the chest to break up tuberculous adhesions, it wasn't until 1991 that that the first successful thoracoscopic lobectomy was first performed by Ralph J. Lewis, MD. ${ }^{18} \mathrm{Dr}$ Lewis had seen the pioneering use of laparoscopy for gynecologic disorders and translated this technology to use in the chest. Subsequent to this, VATS surgery evolved by modifications made by Stephen Hazelrigg, MD, Rodney Landreneau, MD, who I trained with, Keith Nauheim, MD, and Mark Ferguson, MD. In the modern era, I think of Robert McKenna, MD, on the West Coast and Thomas D'Amico on the East Coast as the major teachers and innovators in this field. A minimally invasive approach to lung surgery has been shown to be superior to conventional thoracotomy with respect to length of hospital stay, postoperative pain and recovery, and return to work, ${ }^{19}$ while allowing adequate visualization and not compromising the thoracic surgeon from performing a definitive oncologic resection. ${ }^{20}$ Today, VATS surgery represents one of the greatest advances in thoracic surgery of our generation, bringing a more humane approach to surgery in the chest.

In the same year of 1992, R. Scott Mitchell, MD, and Craig Miller, MD, along with a radiologist, Michael Dake, MD, at Stanford, deployed the first thoracic stent graft in humans, after extensive large animal testing. ${ }^{21}$ Prior to this time, aortic stent grafting, which was in its infancy, was limited to the abdomen. TEVAR was first used to cover acute ruptures and aneurysms of the descending thoracic aorta. After early success with this technique, 
cardiothoracic surgeons rapidly started using TEVAR to cover Stanford type B aortic dissections, to prevent aneurysmal dilatation and rupture of the descending aorta. Familiarity with the technology led to the concept of discrete landing zones in the thoracic aorta, including the ascending aorta and arch, opening up endograft technology to the entire thoracic aorta. To overcome the hurdle of thoracic endografts potentially covering the arch vessels, innovative debranching and hybrid aortic repairs have been devised. ${ }^{22}$ Today, ascending aortic grafts are made with "octopus" extensions that are sewn end-to-end to the arch vessels, when TEVAR "jails" or covers their origin on the aorta.

I am old enough to remember when surgery on acute dissections of the aortic arch, especially where there was poor tissue to sew to, carried a very high mortality. Now, with hybrid debranching techniques and TEVAR, patients have less mortality, fewer cerebrovascular events, and fewer other complications, such as renal failure, compared with an open surgical approach. ${ }^{23}$ I believe that the creativity that was used to develop thoracic aortic stent grafts, with respect to their deployment, sizing, repositioning, and anchoring in the aorta has also been relevant to the development of percutaneous aortic valves.

\section{THE PROMISE OF CRISPR GENOME EDITING-2012}

The future dream that one could someday remove a defective gene that caused a disease and replace it with a new gene is becoming reality with the technology of CRISPR-Cas9 genome editing. CRISPR stands for Clustered Regularly Interspaced Short Palindromic Repeats, a term that is long and a tongue-twister. In 2012, Jennifer Doudna, $\mathrm{PhD}$, at the University of California, Berkeley, was the first to propose that CRISPR could be used for programmable editing of genomes, ${ }^{24}$ which is now considered one of the most significant discoveries in the history of biology. The discovery of CRISPR technology started as a basic science research project investigating how bacteria fight off viral infections.

When a virus infects a bacterium, it injects its DNA into the organism. Most bacteria have a specific locus in their DNA that consists of regularly-spaced repetitive sequences, called the CRISPR array. If the bacterium has a CRISPR array, it can integrate pieces of viral DNA into the array between the CRISPR repetitive sequences. The bacteria then make an RNA copy of the CRISPR array, which is cleaved into smaller units that contain one of the viral RNA sequences and a single CRISPR RNA repeat. These RNA pieces combine with a second RNA, called tracer RNA, and the RNA complex then binds to the protein, CRISPRAssociated Protein 9 (Cas9), that is capable of cutting DNA. The RNA-Cas9 complex surveys the bacterial genome looking for DNA that has a sequence that matches the RNA sequence in the RNA-Cas9 complex. The Cas9 protein unwinds the DNA at that specific site of DNA-RNA homology, allowing RNA-DNA hybridization to occur, and ultimately makes a double-stranded DNA cut at that site. The double-stranded DNA break leads to degradation of viral DNA within the bacterial genome. Thus, CRISPR is a mechanism of adaptive immunity that bacteria possess to survive viral infection. ${ }^{25}$ It allows bacteria to record viruses they have been exposed to within their DNA and pass this record of immunity on to their progeny.

Dr Doudna realized that the mechanism of CRISPR had the potential to be harnessed for genome editing, similar to how we use a word processor to correct a typographical error. Introduction of a CRISPR system into a mammalian cell allows cells to repair double-stranded DNA breaks, by either direct repair of the DNA break site or by integrating a new piece of DNA at the repair site. By targeting site-specific breaks into cellular DNA, she showed that we have the ability to edit out deleterious genes and replace them with normal genes. ${ }^{26}$ Examples of this powerful technology include removing HIV genes from human cells, destroying papillomavirus DNA causing cervical and throat cancers, correcting single-gene mutation diseases such as thalassemia, sickle cell disease, or Duchenne muscular dystrophy, and disrupting the amyloid precursor protein gene to prevent Alzheimer's disease. With this technology comes the potential for germline editing and human enhancement, which raises multiple ethical questions. ${ }^{27}$ Hopefully, this technology will be used for the benefit of individuals suffering from disease and their genetically-related descendants, rather than in the alteration of the human genome for nefarious reasons.

\section{CHIMERIC ORGANS-2017}

Nowhere in medicine do the fields of molecular biology and surgery merge as elegantly as in the advent of chimeric organs. In Greek mythology, a chimera is a gigantic firebreathing beast composed of different parts of more than one animal, vividly depicted in Homer's Iliad as a lionheaded creature with the body of a goat and the tail of a serpent. In modern bioscience, chimeras are animals made up of cells from different organisms. For example, mammalian interspecies chimeras are derived from different species of mammals. They have recently garnered attention among researchers and the public, owing to their potential for providing replacement human organs.

The ability to grow entire body parts for patients in another animal host is the holy grail of regenerative medicine. We all know that the main limiting issue for heart and lung transplant is the number of donor organs available. In 2017, there were 115,000 people on the United Network for Organ Sharing list, with only 34,770 organ transplants performed that year. ${ }^{28}$ In 2018, 3408 heart transplants and 
2530 lung transplants were performed, with, as of December 31, 2018, 3789 individuals still listed for a heart transplant and 1457 waiting for a lung for transplant. ${ }^{29}$

In 2010, 2 scientists, Juan Carlos Izpisua Belmonte, PhD, of the Salk Institute and Hiromitsu Nakauchi, MD-PhD, of Stanford University asked the simple questions, "Can we grow a rat organ in a mouse?" and if successful, can this technology be used to grow a human organ in a pig or primate? They reasoned that the blastocyst, or 40- to 60-cell stage of a rodent embryo, is an immune-protected environment, since immune cells do not exist at this point in development. Yamaguchi's initial experiment was to try to grow a rat pancreas in a mouse. ${ }^{30} \mathrm{He}$ took a single mouse-fertilized oocyte and with CRISPR removed the Pancreas and Duodenal Homeobox 1 gene $(\operatorname{Pdx} 1)$, the earliest gene known for pancreatic development, thereby creating a $\mathrm{Pdx}^{-/-}$zygote. He then cultured green fluorescent protein (GFP)-labeled rat skin fibroblasts and by well-known techniques of reprogramming (retroviral delivery of OCT4, SOX2, KLF4, and MYC), created rat-induced pluripotential stem cells (iPSCs). As you know, use of germline stem cells for research in this country is illegal. However, it is legal to create and work with iPSCs derived from mature cell types. After creating rat iPSCs, Yamaguchi used CRISPR to remove brain lineage genes from them, having the ethical concern that he did not want to create a chimeric animal that had brain tissue derived from 2 different species. He then injected the rat $\mathrm{Pdx}^{+/+}$iPSCs into the $\mathrm{Pdx}^{-/-}$mouse blastocyst. The blastocyst was implanted in a pseudopregnant mouse, and the progeny born were mice with genotypic and phenotypic rat pancreas. The chimeric rat pancreas had the morphology and microscopic anatomy of a rat and produced insulin, such that the mice had normal glucose tolerance tests. The chimeric rat pancreas had $100 \%$ of cells expressing GFP (marker of rat-derived cells), had normal functioning islet cell clusters, as well as other cells that produced glucagon and somatostatin, in response to appropriate stimuli.

The Salk Institute and Stanford groups then published a similar experiment, where they created a rat heart in a mouse. $^{31}$ The NK2 homeobox 5 gene $(\mathrm{Nkx} 2.5)$ plays a critical role in the earliest stages of cardiogenesis, and $\mathrm{Nkx} 2.5^{-/-}$embryos are embryonic lethal at 10.5 days of gestation. After creating $\mathrm{Nkx} 2.5^{-1-}$ mouse blastocysts, they injected $\mathrm{Nkx} 2.5^{+/+}$rat iPSCs into the blastocysts in vitro and subsequently implanted them into a pseudo-pregnant mouse. The resultant mouse embryos had normal gestational growth and had morphologic rat hearts, composed of rat cardiomyocytes. Thus, genotypic rat hearts were generated in mice. Similarly, in 2019, scientists from Columbia University generated functional lungs via blastocyst complementation in mice lacking genes in foregut endoderm that are required for early lung development. ${ }^{32}$
These proof-of-concept studies may now be expanded beyond rodents to larger animals, whose organs are more similar in size to those of humans. Pig, sheep, monkey, and cow embryos may eventually be complemented with human iPSCs to generate replacement heart and lungs. Human-pig blastocyst and human-cow blastocyst complementation has already been achieved. ${ }^{31}$ These results pave the way for the development of new strategies for generating thoracic organs in large animals. At the current time, federal funding is prohibited for humannonhuman chimeras. However, this has not stopped the California Institute for Regenerative Medicine, funded by California Proposition 71 in 2004, from providing millions of dollars of funding for this effort. Beyond creating human organs for transplantation, this technology holds the promise of generating organs for toxicity studies, improving our understanding of early development, enhancing disease modeling, and promoting therapeutic discovery.

\section{THE CREATIVE PROCESS TODAY}

All of the surgeons and scientists who made these major leaps in cardiothoracic surgery and genetics were individuals who were optimistic and believed that their ideas, operations, and experiments would be successful. As Winston Churchill once said, "A pessimist sees the difficulty in every opportunity; an optimist sees the opportunity in every difficulty." 33 Now, I would like everyone to participate in a creativity experiment (Video 1). This experiment was actually first done in the 1960s. ${ }^{34}$ I give each of you a small cardboard box filled with thumb tacks, a book of matches, and a candle. The assignment is to use these items to devise a way to affix a lit candle to a wall. When this psychology experiment was initially performed, individual test subjects were divided into 3 groups. The first group was told that if they could devise a solution to the aforementioned assignment within 5 minutes, they would each receive $\$ 20.00$. The second group was told that they could take as much time as they wanted

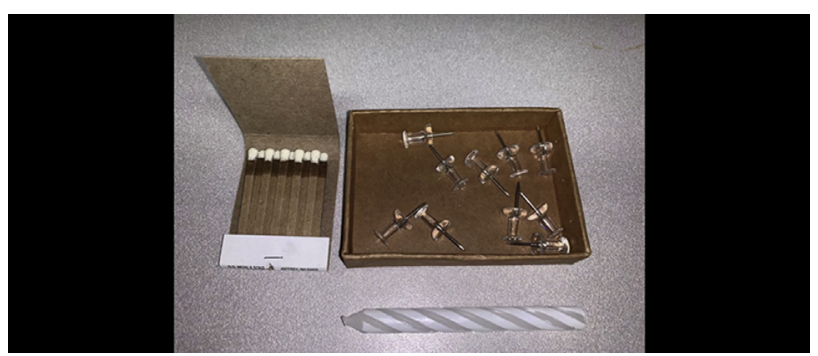

VIDEO 1. Glucksberg candle task: a cognitive performance test. Video available at: https://www.jtcvs.org/article/S0022-5223(20)31406-9/fulltext. 
to think about the solution but would only receive $\$ 20.00$ if they correctly solved the problem. Finally, the third group was told that they could take as much time as they wanted and that there would be no financial reward. The solution that most individuals in Group 1 and 2 devised was to pin the candle directly to the wall with a thumb tack. As the candle was almost as thick as the thumb tack, this method did not work, with the candle falling off the wall in seconds. In contrast, the solution that most people in Group 3 devised was to: empty the thumb tacks from the box, affix the box to the wall using the thumb tacks, light the candle and drip wax into the bottom of the box, and embed the candle into wax so that it stood upright and burning. The conclusion of this experiment was that people who had time to think and imagine would be the most creative, whereas people who were incentivized by money had the least creativity.

How do we define creativity? There are many definitions, but these are the ones I like the best:

1. the defeat of habit by originality;

2. the ability to look at a problem and see new solutions;

3 . the capacity to make connections between unrelated ideas; and

4. just connecting the dots

Many of you will say, "I'm just not a creative person. I just want to do my cases for the day and go home." But I would challenge you that each of us has creative moments, and we are surrounded by creativity. Stuart Jamieson, my former chairman, spent much of his career refining and perfecting the pulmonary endarterectomy operation for relief of chronic thromboembolic pulmonary hypertension. When he did not have the instrument that he wanted to perform a successful endarterectomy of the pulmonary vascular tree, he developed a new one that we call the "Jamieson sucker." This dissector-aspirator is a reusable balltipped, narrow-diameter metal suction instrument that he used to develop an endarterectomy plane within the pulmonary vascular tree. The suction feature allowed for excellent visualization of the endarterectomy by removing blood that could obscure the surgeon's view. I believe that this is quite an innovative instrument, which many of the surgeons in our group use in other operations too. Sarah Blair is a general surgeon at UCSD. When she got tired of waiting for incorrect sponge counts to be correct in the operating room, she and her husband who is an engineer, developed the surgical sponge detector wand, that is now used in most operating rooms across the country. This is a great invention that saves time and gets rid of our frustration as we search for missing gauze sponges in the chest.

There are many barriers to creative thinking in the hospital setting. Evidence-based guidelines force us into conformity for better patient outcomes. However, evidence-based guidelines also stifle creativity, block innovation, and hamper the introduction of new ways to do things that are not time-tested. Quality care assessment pervades our practices. Individual productivity and performance are evaluated in comparison with other surgeons, not just with respect to outcomes and patient well-being, but also with respect to dollars spent per patient and time taken in the operating room. The specter of money is corrupting and cripples innovation. I doubt whether many of the operations I described over the past 60 years would have been allowed by the institutional review board at UCSD. Now, innovative advances in surgery and other procedures have to undergo months of institutional review board review and voluminous paperwork documentation before approval. While patient safety is paramount, new operations and techniques may be lifesaving too. It also is well known that there is rigorous regulation of scientific ideas in that the NIH tends to fund R01 grants that are based on extensive previous investigator research, rather than funding grants that have novel ideas and are high risk. Many of us work in an environment where our worth (and salary) is determined only by the amount of relative value units (RVUs) we generate. This leads to little time for other activities, such as clinical or basic science research and teaching, as we frenetically focus on generating our livelihoods. RVU-based compensation devalues innovation. Finally, there are obviously medico-legal risks when considering creative new ways to do something.

There are also personal barriers to creative thinking. To some extent, we all have a fear of failure, and this grows as we age. Once we are good at something, we have a desire to stay in our comfort zone and not try anything new or different from the status quo. We are often bombarded with too many time-consuming tasks to have time to think or reflect about how things could be done better. All those e-mails and texts that we get every day, are they really that important to consume so much of our time? There is

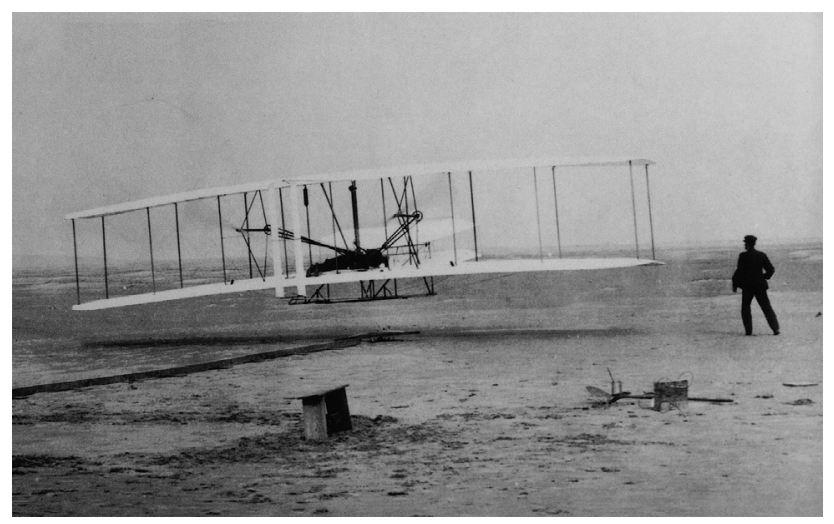

FIGURE 3. The first flight by the Wright brothers on December 17, 1903. Orville Wright piloted the gasoline-powered, propeller-driven biplane which stayed aloft for 12 seconds and covered 120 feet. Wilbur Wright ran next to the right wing. 
also an unwritten social conformity amongst cardiothoracic surgeons in that we often emulate the busiest surgeon in the group or force ourselves to conform to the behavior that is "macho" or similar to everyone else. Finally, it is easy to have contentment with the status quo, and it takes effort to think outside of the box and accept failure in new endeavors. We need to remember what Nelson Mandela said as he reflected about his own life, "There are no failures in life, only learning experiences." 35

Where do we find inspiration for our creativity? I grew up spending my summers in a beach cottage a few miles from where the Wright brothers made the first flight on December 17, 1903, in Kitty Hawk, North Carolina. This site has been a lifelong source of inspiration for me and a place of reflection (Figure 3). I have walked the field where the first 3 Wright brothers' flights took place, in the howling cold winds of November and the warm sunshine of June. Rough-hewn stone monuments mark the beginning and ending spots of these fledgling flights. I have always marveled about how 2 brothers, one shy, bookish, and socially awkward; the other extroverted, talkative, and overly self-confident, could work together to create one of the greatest inventions of the 20th century.

Necessity also drives creativity. I think that one of the best examples of this is the Apollo 13 mission to the moon in 1970. When Jim Lovell, Jack Swigert, and Fred Haise were 205,000 miles into their trip and Apollo 13 was entering orbit around the moon, an explosion occurred in the oxygen tank of the command module. This explosion disabled and partially destroyed the lithium hydroxide canisters that were used to remove carbon dioxide from the spacecraft. Shortly after the explosion, the spacecraft passed around the back side of the moon and communications from the ground were suspended. Knowing that they only had a few hours to fix the problem, else they would die of carbon dioxide asphyxia, the astronauts put their heads together to develop a solution. The astronauts devised an ingenious way to connect the cube-shaped command module lithium hydroxide canisters with the lunar module cylindrical canister-sockets, by drawing air through them using a space suit hose, duct tape, a heavy brown plastic garbage bag, and a metal box. The end result was that they re-established extraction of carbon dioxide from the command module and returned to earth safely, without landing on the moon. In this life-threatening situation, there were no egos driving key decisions. The astronauts collectively brainstormed the problem and worked as a team. The best idea won and was successful, under what was an extraordinary amount of pressure. To this day, Apollo 13 holds the spaceflight record marking the farthest humans have traveled from the earth-248,655 nautical miles from the earth as it orbited around the back side of the moon.
How do we enhance our personal creativity? Here are some of my thoughts:

1. Be open-minded and curious. Most of us are in this field because we have a natural curiosity about how to fix the body. Solutions to problems come from many places other than the operating room.

2. Set far-reaching goals. You will never cure cancer, if you do not believe that you will.

3. Be positive about new ideas. What sounds like a stupid idea may, in fact, be a new way of seeing or solving a problem.

4. Find time to let your mind wander. I think of the example of Archimedes. Archimedes was ordered by the King of Syracuse to devise a way to determine if a crown was made of gold or was fake metal. He had to solve the problem without damaging the crown, so he could not melt it down into a regular shape to calculate its density. He worked on this problem for days, without finding a solution. While stepping into a warm bath, he noticed that the level of water in the tub rose as he submerged himself. Archimedes realized that this effect could be used to determine the volume of the crown. The submerged crown would displace an amount of water equal to its own volume. By dividing the mass (weight) of the crown by the volume of water displaced, the density of the crown was calculated. The density would be lower than that of gold if cheaper and less dense metals had been used or added. When he discovered that the crown was indeed fake and mixed with silver, he was so excited by his discovery that he took to the streets naked, crying, "Eureka! I have found it!" By taking the time, to let his mind wander in the bathtub, Archimedes gave birth to the famous principle that bears his name.

5. Engage with people who have different professional and educational backgrounds from you. Sometimes you will find that thinking about a problem through the eyes of individuals who are different from you will yield answers.

6. Do not let accidents annoy you. Remember the Scottish physician and microbiologist, Alexander Fleming? On an August day before leaving for vacation, he left several petri plates on his lab bench that were meant to be thrown away. When he returned to the lab from his holiday, Fleming found that one plate was contaminated with a fungus, and that the colonies of staphylococci immediately surrounding the fungus had been destroyed. He grew the mold in a pure culture and found that it produced a substance that killed a number of disease-causing bacteria. He named this substance penicillin and the fungus that produced this substance Penicillium notatum. Without the simple mistake of leaving petri plates unattended, the discovery of 
antibiotics may have occurred years later. Fleming won the Nobel Prize in Medicine in 1945 for his discovery of penicillin.

7. Avoid rote learning. Brain-numbing exercises will kill your creativity.

8. Do something physical. In psychology experiments, people who are physically active are more likely to solve problems, come up with answers quickly, and be more optimistic about life.

9. Leave some things undone. Sometimes the best approach is to put a problem aside, think about something else, and return to a problem later.

10. Support colleagues and share ideas. I suspect that most surgeons in this room, at one point in their career, have been in the operating room, when something has gone wrong or was unanticipated and thought, "What do I do now?" These moments lead to creative solutions. If nothing else, support your fellow surgeons in their creative endeavors, whether they be clinical or researchoriented. Often bouncing around a problem amongst a group will lead to new approaches and solutions.

Tim Harford is an economist, columnist for the Financial Times, and writer. He is the best-selling author of books entitled, Adapt: Why Success Always Starts With Failure, Fifty Innovations that Shaped the Modern Economy, and Messy: The Power of Disorder to Transform our Lives. $\mathrm{Mr}$ Harford has popularized the notion of "Slow-Motion Multi-tasking." We all think of multi-tasking as an efficient way to help us get through our hectic days. However, the concept of slow-motion multi-tasking is something different. In slow-motion multi-tasking, everyone should pick several projects or problems that interest them over a long period of time. When one is stuck on a problem, not finding an immediate solution, and becoming frustrated or ineffective, the best approach is to put the problem down and think about another project or problem. This way, your mind is shifting back and forth between different ideas and solutions. He suggests that in order for slow-motion multi-tasking to be effective, one must be optimistic and believe that he/she will eventually find answers and solutions to challenging projects and problems.

One of the best examples of a person who was a slowmotion multi-tasker was Michael Crichton. Michael Crichton was a physician, author, screenwriter, film director, computer programmer, and television producer. As a medical student at Harvard, he wrote 10 books, including the bestseller, The Andromeda Strain. He left medicine after medical school, as he thought that it was a profession where he was always in a position of uncertainty and not knowing how to do something. However, Crichton wrote that medical training got him in the frame of mind of dealing with high-pressure situations, dealing with multiple complex factors at the same time, making quick decisions during emergencies, and rapidly assessing people he had not met before. He used these skills, bouncing between writing bestselling medical thrillers, creating code for video games, directing movies, and writing screenplays for television and the big screen, often working on multiple ideas at one time. In 1995, he had the most commercially successful bestselling book, highest-grossing movie, and mostwatched television show in the United States, a feat that he repeated again in 1996.

The playwright George Bernard Shaw once wrote, "We don't stop playing because we get old. We get old because we stop playing." ${ }^{36}$ Roger Tsien, $\mathrm{PhD}$, was a researcher whose lab was 2 floors below my lab. He grew up on the Jersey shore and was the son of emigrants from China. Since childhood, he was fascinated with how jelly fish fluoresce green at night. Roger started his career at the University of California, Berkeley, imaging neural activity by trying to develop tracers of sodium and calcium ion movement in neurons. Unfortunately, he was denied tenure and running out of grant money for his lab, he left and surfed and bicycled around the Pacific Northwest for a year. In 1989, he accepted a position at UCSD and began to study what interested him since youth: fluorescence of cells and proteins. Roger's lab pioneered the development of green fluorescent protein (GFP) variants. Through a combination of rational design and random mutagenesis, he created dozens of bright, different-colored, fluorescent proteins based on GFP. He took great pleasure in naming probes after fruits and vegetables, such as tomato, cherry, and plum. Today, GFP variants are ubiquitous in biological research and clinical imaging. Roger often credited his success to his time spent surfing and riding his bike, where he could think freely. For his contributions to medical science, Roger Tsien was awarded the Nobel Prize in Medicine at age 56 in 2008.

Thus, as Steve Jobs so eloquently put it, "Here's to the crazy ones. The rebels. The troublemakers. The round pegs in the square holes. The ones who see things differently. They're not fond of rules, and they have no respect for the status quo. You can quote them, disagree with them, glorify or vilify them, but the only thing you can't do is ignore them, because they change things. They push the human race forward. And while some may see them as the crazy ones, we see genius. Because the people who are crazy enough to think they can change the world are the ones who do." 37

The Japanese have a word, ikigai (pronounced Eye-kuyguy), which sums up the overlapping elements that one needs to lead a creative and fulfilling life (Figure 4). The concept of ikigai or "reason for being" originated in Okinawa, where there is the largest population of centegenerians in the world. To be the most creative, one needs a convergence of 4 primary elements, by doing: 


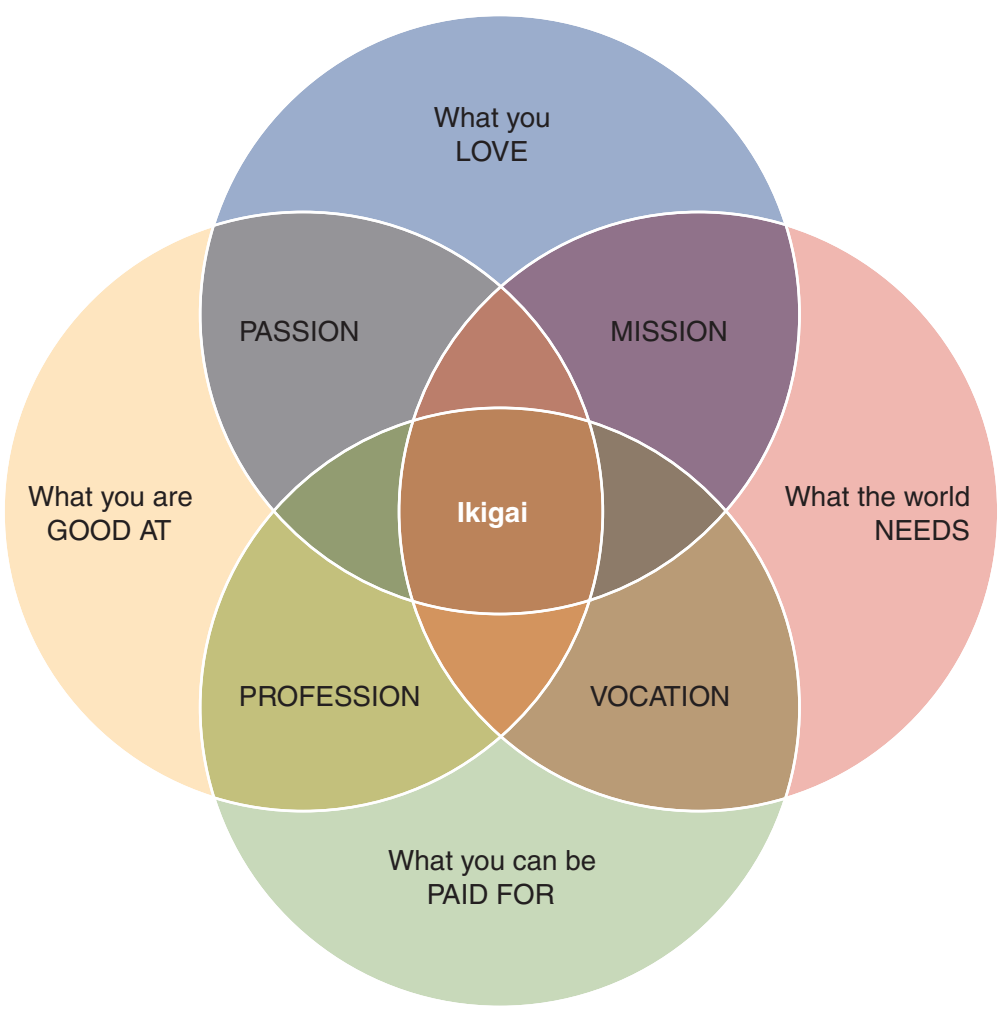

FIGURE 4. The elements of the Japanese concept of ikigai.

1. what you love (your passion),

2. what the world needs (your mission),

3. what you are good at (your vocation), and

4. what you get adequately paid for (your profession).

To the Japanese, when these 4 elements are obtained, the individual has a source of value and starting point for a creative life. I think that all of us can look at these categories and figure out which ones we have in our careers and which elements we still need to work on. Ikigai ties into the idea that we all have potential beyond our quotidian lives. Similarly, there is a Welsh proverb that I have heard since childhood, that in a simple way embodies our potential, "A seed hidden in the heart of an apple is an orchard invisible."

Creativity is something that changes as we grow older and gain more knowledge and experience. The wildly creative things we do as twenty-year-olds are different from the creative endeavors we have in our sixties. Cardiothoracic surgery is a profession where we have a lifetime of learning. Learning and the creative process are inextricably linked. As we gain knowledge, we acquire wisdom, sagacity, and perspective. I think the concept that discovery and creativity are lifelong processes, and that they bring personal fulfillment is best embodied in the epic poem Ithaka by the Greek poet, C. P. Cavafy. ${ }^{38}$ In his poem, he writes about Odysseus, who after years of travel and adventure, returns to his beloved homeland of Ithaka, now as an old man, looking for meaning in his life:

"As you set out for Ithaka, hope the voyage is a long one,

Full of adventure, full of discovery.

Arriving there is what you are destined for.

But do not hurry the journey.

Better if it lasts for years, so you are old by the

Time you have reached there.

Wealthy with all you have gained on the way.

And if you find her poor, Ithaka won't have fooled you.

Wise as you will have become, so full of experiences You will understand what Ithaka means."

A lifetime of learning, creativity, our surgical home.

So, as you go forth into the Lake Tahoe sunshine and later back to your practices, I ask of you, as the Pulitzer Prize-winning poet, Mary Oliver asked in her poem, "The Summer Day,", "Tell me, what is it you plan to do with your one wild and precious life?"

\section{References}

1. Hagia Sophia. Available at: https://en.wikipedia.org/wiki/Hagia_Sophia. Accessed October 1, 2019. 
2. Mainstone RJ. Hagia Sophia: Architecture, Structure, and Liturgy of Justinian's Great Church. 1st ed. London: Thames and Hudson; 1988.

3. Florence Cathedral. Available at: https://en.wikipedia.org/wiki/Florence Cathedral. Accessed October 1, 2019.

4. King R. Brunelleschi's Dome: How a Renaissance Genius Reinvented Architecture. 1st ed. London: Chaatto and Windus; 2000.

5. Lillihei CA, Gott V, Hodges P, Long DM, Bakken EE. Transistor pacemaker for treatment of complete atrioventricular dissociation. J Am Med Assoc. 1960;172: 2006-10.

6. Elmqvist R, Senning A. An implantable pacemaker for the heart [abstract] Second International Conference on Medical Electronics. 1960. In: Aquilina, O. A brief history of cardiac pacing. Images Paediatr Cardiol. 2006;8:17-81.

7. Puette JA. Pacemaker. StatPearls - NCBI Bookshelf. Treasure Island, FL: Stat Pearls Publishing; 2018. Available at: https://www.ncbi.nlm.nih.gov/books/ NBK526001/. Accessed October 1, 2019.

8. Ho JS, Yeh AJ, Neofytou E, Kim S, Tanabe Y, Patlolla B, et al. Wireless power transfer to deep-tissue microimplants. Proc Natl Acad Sci USA. 2014;111: 7974-9.

9. Lawrence PA. Francis Crick: s singular approach to scientific discovery. Cell. 2016;167:1436-9.

10. Nirenberg MW, Matthaei JH. The dependence of cell-free protein synthesis in e coli upon naturally occurring or synthetic polyribonucleotides. Proc Natl Acad Sci U S A. 1961;47:1588-602.

11. Nirenberg MW, Matthaei JH, Jones OW, Martin RG, Barondes SH. Approximation of genetic code via cell-free protein synthesis directed by template RNA. Fed Proc. 1963;22:55-61.

12. Varmus H. The molecular genetics of cellular oncogenes. Ann Rev Genet. 1984; 18:553-612.

13. Spector DH, Varmus HE, Bishop JM. Nucleotide sequences related to the transforming gene of avian sarcoma virus are present in the DNA of uninfected vertebrates. Proc Natl Acad Sci U S A. 1978;75:4102-6.

14. Yoda S, Dagogo-Jack I, Hata AN. Targeting oncogenic drivers in lung cancer: recent progress, current challenges and future opportunities. Pharmacol Ther. 2019;193:20-30

15. Maguire FB, Morris CR, Parikh-Patel A, Cress RD, Keegan TH, Li CS, et al First-line systemic treatments for stage IV non-small cell lung cancer in California: patterns of care and outcomes in a real-world setting. JNCI Cancer Spectr. 2019;3:pkz020.

16. Carpentier A. Cardiac valve surgery-the "French correction". J Thorac Cardi ovasc Surg. 1983;86:323-37.

17. Jouan J. Mitral valve repair over 5 decades. Ann Cardiothorac Surg. 2015;4:322-34

18. Lewis RJ, Caccavale RJ, Sisler GE, Bocage JP, Mackenzi JW. One hundred video-assisted thoracic surgical simultaneously stapled lobectomies without rib spreading, Ann Thorac Surg. 1997;63:1415-21.

19. Whitson B, Groth SS, Duval SJ, Swanson SJ, Maddaus MA. Surgery for early-stage non-small cell lung cancer: a systematic review of the videoassisted thoracoscopic surgery versus thoracotomy approaches to lobectomy. Ann Thorac Surg. 2008;86:2008-16.
20. Nakao M, Ichinose J, Matsuura Y, Nakagawa K, Okumura S, Mun M. Long-term oncological outcome after thoracoscopic lobectomy for non-small cell lung cancer patients. J Thorac Dis. 2019;11:3112-21.

21. Semba CP, Kato N, Kee ST, Mitchell RS, Miller DC, Dake M. Acute rupture of the descending thoracic aorta: repair with use of endovascular stent-grafts. $J$ Vasc Interv Radiol. 1997;8:337-42.

22. Kamiya H, Nakanishi S, Ise H, Kitahara H. Total debranching hybrid total arch replacement with a novel frozen elephant trunk for acute aortic dissection type A. J Thorac Cardiovasc Surg. July 19, 2019 [Epub ahead of print].

23. Preventza O, Tan CW, Orozco-Sevilla V, Euhus CJ, Coselli JS. Zone zero hybrid arch exclusion versus open total arch replacement. Ann Cardiothorac Surg. 2018; 7:372-9.

24. Jinek M, Chylinski K, Fonfara I, Hauer M, Doudna JA, Charpentier E. A programmable dual RNA-guided DNA endonuclease in adaptive bacterial immunity. Science. 2012;337:816-21.

25. Barrangou R, Fremaux C, Deveau H, Richards M, Boyaval P, Moineau S, et al. CRISPR provides acquired resistance against viruses in prokaryotes. Science. 2007;315:1709-12.

26. Sternberg SH, Doudna JA. Expanding the biologist's toolkit with CRISPR-Cas9 Mol Cell. 2015:58:568-74.

27. Brokowski C, Adli M. CRISPR ethics: moral considerations for applications of a powerful tool. J Mol Biol. 2019;431:88-101.

28. United Network for Organ Sharing. Available at: https://unos.org/data/ transplant-trends/. Accessed October 1, 2019.

29. Organ Procurement and Transplantation Network. Available at: Optn.transplant. hrsa.gov. Accessed October 1, 2019.

30. Kobayashi T, Yamaguchi T, Hamanaka S, Kato-Itoh M, Yamazaki Y, Ibata M, et al. Generation of rat pancreas in mouse by interspecific blastocyst injection of pluripotent stem cells. Cell. 2010;142:787-99.

31. Wu J, Platero-Luengo A, Sakurai M, Sugawara A, Gil MA, Yamauchi T, et al. Interspecies chimerism with mammalian pluripotent stem cells. Cell. 2017; 168:473-86.

32. Mori M, Furuhashi K, Danielsson JA, Hirata Y, Kakiuchi M, Lin CS, et al. Generation of functional lungs via conditional blastocyst complementation using pluripotent stem cells. Nat Med. 2019;25:1691-8.

33. Churchill W. In: Penberthy I, ed. Churchill in Quotes: Wit and Wisdom from the Great Statesman. 1st ed. London: Ammonite Press; 2011.

34. Glucksberg S. The influence of strength of drive on functional fixedness and perceptual recognition. J Exp Psychol. 1962;63:36-41.

35. Mandela N. Nelson Mandela's Quotes and Tributes. 1st ed. Wiltshire, UK: AA Global Sourcing Ltd; 2013.

36. Shaw GB. 7-Ingenious George Bernard Shaw Quotes. Available at: https:// exploringyourmind.com. Accessed October 1, 2019

37. Jobs S. Apple TV advertisement: Think Different; 1997. Available at: https:// www.youtube.com/watch?v=lEhQSdmFMpY. Accessed October 1, 2019.

38. Cavafy CP. Ithaka. In: Sharon A, ed. Selected Poems of C.P. Cavafy. 1st ed. Harmondsworth, UK: Penguin Press; 2008.

39. Oliver M. The summer day. In: House of Light. 1st ed. Boston: Beacon Press; 1990. 